\title{
Composition and structure of fish assemblage from Passa Cinco stream, Corumbataí river sub-basin, SP, Brazil
}

\author{
Carmassi, AL. ${ }^{a}{ }^{*}$, Rondineli, G. $^{b}$, Ferreira, FC. ${ }^{c}$ and Braga, FMS. ${ }^{a}$

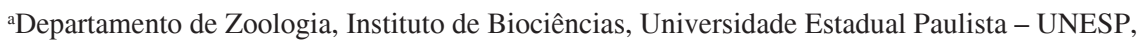 \\ Av. 24A, 1515, Bela Vista, CP 199, CEP 13506-900, Rio Claro, SP, Brazil

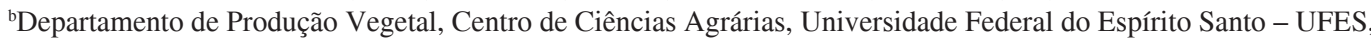 \\ Alto Universitário, s/n, Guararema, CP 16, CEP 29500-000, Alegre, ES, Brazil \\ 'Departamento de Ecologia, Instituto de Biociências, Universidade Estadual Paulista - UNESP, \\ Av. 24A, 1515, Bela Vista, CP 199, CEP 13506-900, Rio Claro, SP, Brazil \\ *e-mail: alberto.carmassi@gmail.com
}

Received December 9, 2010 - Accepted April 13, 2011 - Distributed February 29, 2012

(With 10 figures)

\begin{abstract}
The aim of this work was to determine the composition of the fish assemblage of Passa Cinco stream and verify changes in their structure on the altitudinal gradient. Six samples were performed at five different sites in Passa Cinco stream (from the headwater, at order two, to its mouth, at order six), using an electric fishery equipment and gill nets in May, July, September and November of 2005 and January and March of 2006. The indices of Shannon's diversity, Pielou's evenness and Margalef's richness were quantified separately considering the different fishery equipment (nets versus electric fishery equipment). An ANOVA was used to compare samples collected in relation to values of abundance, diversity, evenness and richness. The representativeness of the species was summarised by their average values of abundance and weight. We captured 5082 individuals distributed into 61 species. We observed a trend of increasing diversity, richness and evenness of species from site 1 to 3 , with further decrease in sites 4 and 5 . The values found for habitat diversity also followed this pattern. Significant differences were found for all three indices considering the electric fishery samples. For individuals caught with nets, only the richness index showed a significant difference. Characidium aff. zebra was an important species in the headwater and transition sites and Hypostomus strigaticeps in middle-lower course sites. Despite the small extension of the Passa Cinco stream, environments structurally well defined were evidenced by the species distribution and assemblage composition along the gradient.
\end{abstract}

Keywords: ichthyofauna, species diversity, altitudinal gradient, river continuum concept.

\section{Composição e estrutura da assembleia de peixes do Rio Passa Cinco, sub-bacia do rio Corumbataí, São Paulo, Brasil}

\section{Resumo}

O objetivo desse trabalho foi determinar a composição da assembleia de peixes do Rio Passa Cinco, além de verificar alterações em sua estrutura em função do gradiente altitudinal. Foram realizadas seis amostragens em cinco pontos distintos no Rio Passa Cinco (contemplando trechos de ordem dois, três, quatro, cinco e seis), fazendo uso de pesca elétrica e redes de espera, nos meses de maio, julho, setembro e novembro de 2005 e janeiro e março de 2006 . Os índices de diversidade de Shannon, equidade de Pielou e riqueza de Margalef foram quantificados separadamente, considerando as diferentes artes de pesca (redes versus pesca elétrica). Foi utilizada a ANOVA para comparar os pontos de coleta quanto aos valores médios de abundância, diversidade, equidade e riqueza. A representatividade das espécies foi resumida pelos seus valores médios de abundância e peso. Foram capturados 5082 indivíduos distribuídos em 61 espécies. Foi observada uma tendência de aumento de diversidade, riqueza e equidade das espécies do ponto 1 ao 3 , com posterior queda nos pontos 4 e 5, indo ao encontro com os valores de diversidade de habitat, que também seguiram esse padrão. Foram encontradas diferenças significativas para os três índices considerando as amostras de pesca elétrica. Para os indivíduos capturados com redes, apenas o índice de riqueza apresentou diferença significativa. Characidium aff. zebra foi uma espécie importante nos trechos de cabeceira e transição, e Hypostomus strigaticeps nos trechos de médio-baixo curso. Apesar da pequena extensão do Rio Passa Cinco, ambientes estruturalmente bem definidos foram evidenciados pela distribuição das espécies e pela composição da assembleia ao longo do gradiente.

Palavras-chave: ictiofauna, diversidade de espécies, gradiente altitudinal, conceito do rio contínuo. 


\section{Introduction}

Fish distribution in an environment is rarely caused by a single factor. Changes in the fish species composition from the headwaters to the lower parts is a common phenomenon and conceptual models based on temperate rivers seek to explain the mechanisms responsible for these processes (Matthews, 1998). Geomorphology is an important factor affecting the structure of fish communities in lotic environments (Allan, 1997), because from the headwaters to the mouth, the river goes through different terrain features, leading to changes in limnological characteristics and structural environment.

According to the river continuum concept (Vannote et al., 1980), we expect a gradual increase in species richness along the gradient, and the area of the middle section as the most diverse. These changes usually are associated with habitat changes along the gradient (Gorman and Karr, 1978). Matthews and Styron (1981) also suggested that the physical and chemical conditions in the headwaters are more stressful than in the lower portions, so that few fish species can colonize these areas.

Spatial patterns of species distribution have been addressed in several studies (Uieda, 1984; Garutti, 1988; Uieda and Barreto, 1999; Silvano et al., 2000; Mazzoni and Lobón-Cerviá, 2000; Uieda and Uieda, 2001; Pavanelli and Caramaschi, 2003; Castro et al., 2003; Súarez and Petrere, 2003; Súarez and Petrere, 2005; Castro et al., 2004; Casatti, 2005; Braga and Andrade, 2005; Cetra and Petrere, 2006) that, in general, reported an increase in species diversity since the headwaters to the mouth in fish communities at different locations. The relationship between habitat and community composition was presented by Montag et al. (1997), Benedito-Cecilio et al. (2004) and Gomiero and Braga (2006), which showed the correlations between habitat diversity and general conditions in the environment.

Among the main patterns of longitudinal variation in stream fishes, there are the species additions and replacements (Gilliam et al., 1993; Petry and Schultz, 2006). Species additions are generally correlated with less severe environmental gradients, leading to smooth changes in abiotic and/or structural factors, while the species replacements occur as a result of abrupt changes in stream geomorphology or are related to abiotic conditions (Balon and Stewart, 1983; Winemiller and Leslie, 1992; Edds, 1993; Jackson et al., 2001; Wilkison and Edds, 2001; Ferreira and Petrere, 2009).

The Passa Cinco stream is one of the main rivers of the Corumbataí river sub-basin, that belongs to the Piracicaba river basin, one of the last options to provide good water quality to several municipalities. Situated next to major urban, agricultural, technological and scientific centres of southeastern Brazil, it has been degraded over a century, through soil use and occupancy, and by excessive withdrawal of water for human consumption and agriculture. Given the regional importance of these water bodies, the aim of this study was to determine the composition of the fish assemblages in Passa Cinco stream and measure the changes in their structure along the longitudinal gradient.

\section{Material and Methods}

This study was accomplished in the Passa Cinco stream, with headwaters localised in the Serra da Cachoeira a component of the complex of Serra de Itaqueri, in the municipal district of Itirapina. The drainage area of Passa Cinco stream is $525 \mathrm{~km}^{2}$, covering about $60 \mathrm{~km}$ from its headwaters (with about $1000 \mathrm{~m}$ ) to its confluence with the Corumbataí river (to $480 \mathrm{~m}$ ) (Garcia et al., 2004). Currently, it has $51.72 \%$ of its area occupied by pastures, $14.13 \%$ by sugar cane, $15.67 \%$ by native forest and $0.74 \%$ by savanna (Valente and Vettorazzi, 2002).

Six samplings were accomplished at five different sites in Passa Cinco stream, contemplating sections of order two, three, four, five and six, according to the Strahler (1952) classification, with the following geographic coordinates: site 1 (order 2) - $22^{\circ} 23^{\prime} 36^{\prime \prime} \mathrm{S}$ and $47^{\circ} 53^{\prime} 08^{\prime \prime} \mathrm{W}$, site 2 (order 3 ) $-22^{\circ} 22^{\prime} 10^{\prime \prime} \mathrm{S}$ and $47^{\circ} 51^{\prime} 22^{\prime \prime} \mathrm{W}$, site 3 (order 4) $-22^{\circ} 21^{\prime} 63^{\prime \prime} \mathrm{S}$ and $47^{\circ} 48^{\prime} 48^{\prime \prime} \mathrm{W}$, site 4 (order 5) - $22^{\circ} 24^{\prime} 74^{\prime \prime} \mathrm{S}$ and $47^{\circ} 43^{\prime} 34^{\prime}$ ' W and site 5 (order 6) $22^{\circ} 30^{\prime}$ ' $97^{\prime \prime} \mathrm{S}$ and $47^{\circ} 39^{\prime}$ '49' $\mathrm{W}$ in the months of May, July, September and November of 2005 and January and March of 2006 (Figures 1 and 2).

In each sample site, the predominant substrate type was recorded, as well as presence/absence of riparian vegetation, degree of shading, type of current and mean depth, as shown by Rondineli and Braga (2009). From these data, the habitat heterogeneity at each site was estimated using the Shannon diversity index (Gorman and Karr, 1978).

The fishery equipment used was electric fishery and gill nets. The electric fishery equipment (which consists of a generator that provides power $-110 \mathrm{~V}$ - for a rectifier current that has the capacity to increase the voltage - up to $1500 \mathrm{~V}$ - and reduce the amperage - to $2 \mathrm{~A}$ ) was used in the first three sites (1, 2 and 3 ). In these sites we performed a downstream-upstream pass at $50 \mathrm{~m}$ stretches without using contention nets. Gill nets (with mesh sizes varying from 3 to $9 \mathrm{~cm}$ between adjacent knots) were used in sites 3, 4 and 5. The sequence of gill nets was determined at random and placed in the afternoon (between 15 and 18 hours) remaining until the following morning. After each collection, fish were put into plastic bags, fixed in $10 \%$ formalin for 2 days and then transferred to $70 \%$ ethanol until the analysis was accomplished. In the laboratory, the fishes were identified to species level, measured for total length $(\mathrm{cm})$ and weighed $(\mathrm{g})$. Voucher specimens were deposited in the Ichthyology Laboratory, Department of Zoology of the Universidade Estadual Paulista, in Rio Claro.

The indexes of Shannon's diversity, Pielou's evenness and Margalef's richness were calculated for each sample site, separating the individuals captured by electric fishery from those captured by gill nets. To determine mean differences, ANOVAs were performed for each index to compare the sites sampled with the same fishery equipment (P1, P2 and P3 - electric fishery and P3, P4 and P5 - gill nets).

The representativeness of the species were summarised by their mean values of abundance $\left(\overline{\mathrm{N}}=\mathrm{N} / \mathrm{F}_{0}\right)$ and weight $\left(\overline{\mathrm{P}}=\mathrm{P} / \mathrm{F}_{0}\right)$, where $N$ is the number of individuals, $\mathrm{P}$ the 
weight and $\mathrm{F}_{0}$ the frequency of occurrence (Ferreira, 2007). Thus, $\bar{N}$ and $\bar{P}$ measure the local importance of each species sampled in each order. The species most and least important were highlighted. This analysis was performed for each sample site, considering the different fishery equipment.

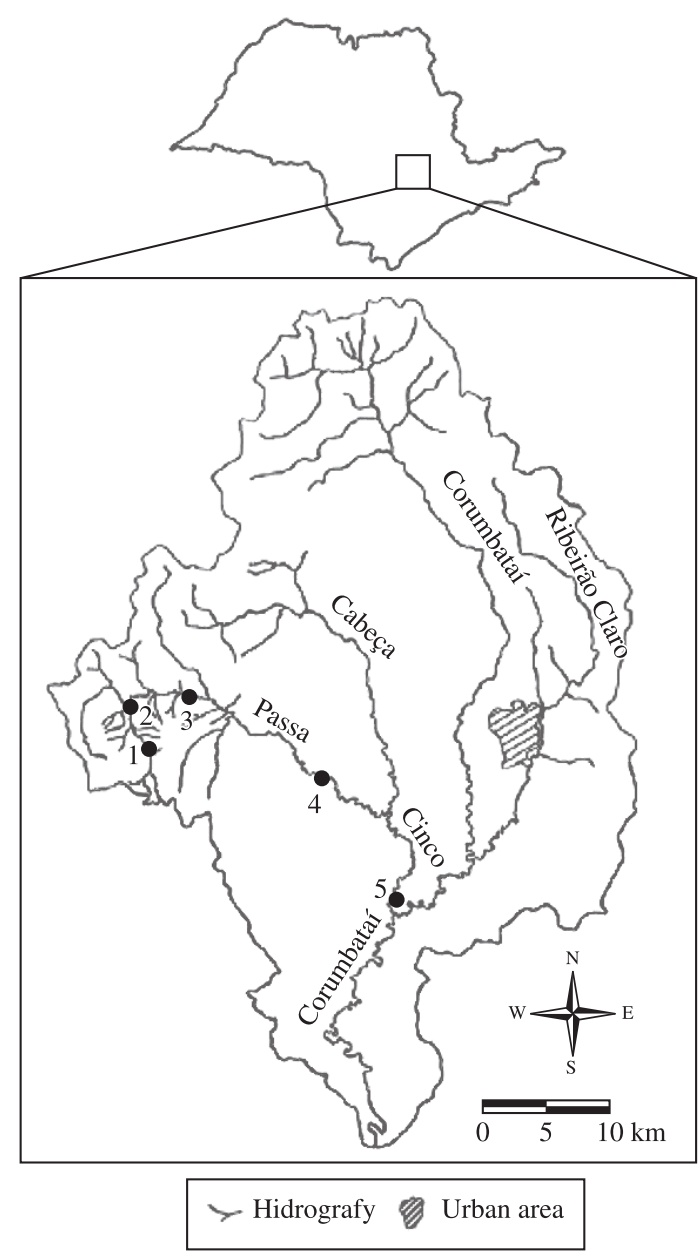

Figure 1. Hydrographic map of the Corumbataí river sub-basin, showing the sampled sites (modified from Garcia et al., 2004) 1) Sample site 1;2) Sample site 2; 3) Sample site 3; 4) Sample site 4; 5) Sample site 5; Urban area - Rio Claro).

\section{Results}

The substrate type changed gradually from site 1 to site 5 , the marginal vegetation (presence of grasses along the streams bank) occurred in all sampling sites, except for site 1. The degree of shading decreased from the headwater to the mouth. The types of predominant current were: riffle in site 1 , riffle and run in site 2 , riffle, run and pool in site 3 and run in sites 4 and 5. The mean depth increased from upstream to downstream (Table 1 and Figure 2). Site 3 showed the highest diversity of habitats, followed by sites 5 and 4 (Figure 3).

We captured 5082 individuals belonging to 61 species. Characidium aff. zebra was the most abundant species (Table 2). The number of individuals, species richness and the indexes of Shannon's diversity, Margalef's richness and Pielou's evenness are shown in Table 3 for each site and fishing gear. The largest catches occurred in sites 3, 2 and 1 sampled with electric fishery. The greatest richness and diversity were obtained in site 3 , regardless of the fishing gear used. The evenness index values for all sites were around 0.8 .

For sites 1 to 3 (electric fishery), the ANOVA showed significant differences $(\mathrm{p}<0.001$, Table 4$)$ in the indexes of richness, diversity and evenness. So we can accept that the Shannon diversity changed due to variation in either richness and evenness. For sites 3 to 5 (gill nets), only the richness index differed significantly $(\mathrm{p}=0.047$, Table 4$)$.

Figure 4 presents the mean values, standard errors and $95 \%$ confidence intervals for the indexes of diversity, richness and evenness as well as for the number of individuals in the five sampling sites, considering separately the sites sampled with electric fishery (sites 1,2 and 3) and gillnets (sites 3, 4 and 5). An increase in diversity, evenness and richness can be found from site 1 to site 3 . Moreover, a decrease in richness was found from site 3 to site 5 , with the lowest value found in site 4 . Regarding the number of individuals, there is a greater abundance in places where electric fishery was used. However, the fishery equipment had more subtle effects on the indexes of diversity, evenness and richness, as shown in site 3 , the only one in which it was possible to apply the two techniques.

When species composition was analysed in terms of mean weight and mean abundance per sample, it is possible to see which will best represent the sampled sites. When considering only the individuals captured with electric fishery Characidium aff. zebra, Trichomycterus sp.1, Imparfinis mirini and Cetopsorhamdia iheringi

Table 1. Bottom type, marginal vegetation, degree of shading, current type and mean width found in each of the sampling sites of Passa Cinco stream.

\begin{tabular}{cccccc}
\hline Sites & Bottom type & Marginal vegetation & Degree of shading & Current type & Mean width (m) \\
\hline 1 & pebble & absent & $>76 \%$ & riffle & shallow \\
2 & pebble gravel & present & $51-75 \%$ & riffle run & shallow \\
3 & pebble gravel sand & present & $26-50 \%$ & riffle run pool & moderate \\
4 & sand & present & $26-50 \%$ & run & Deep \\
5 & sand & present & $0-25 \%$ & run & Deep \\
\hline
\end{tabular}



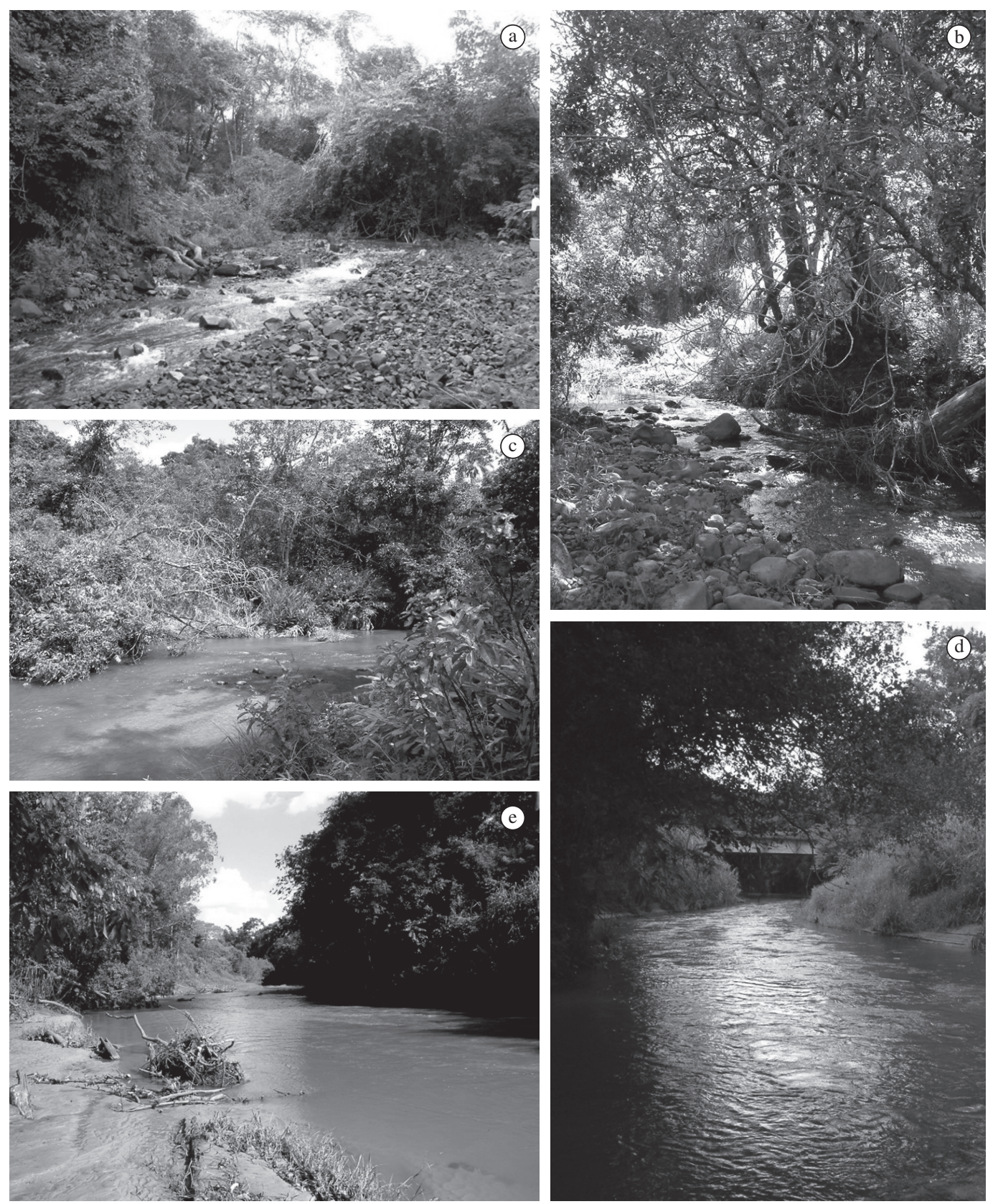

Figure 2. View of the samples sites: a) site 1; b) site 2; c) site 3; d) site 4; e) site 5 .

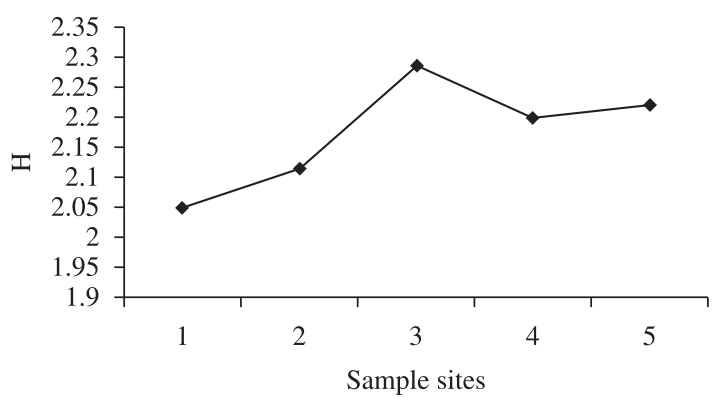

Figure 3. Values of Shannon diversity index for the habitat at each sample site. were the most important species in site 1 (Figure 5); Characidium aff. zebra, Trichomycterus sp.1, Bryconamericus stramineus and B. turiuba in site 2 (Figure 6); and C. aff. zebra, Hypostomus strigaticeps, Parodon nasus and Apereiodon ibitiensis in site 3 (Figure 7). Whereas individuals caught with nets, $H$. strigaticeps was the most important species in site 3 (Figure 8); in site 4, Odontostilbe aff. microcephala, Astyanax sp.1, A. altiparanae and $H$. strigaticeps stood out (Figure 9); and in site 5, H. strigaticeps and A. altiparanae were the most important species (Figure 10). 
Table 2. Fish species caught in the Passa Cinco stream for each sample site in decreasing order of abundance.

\begin{tabular}{|c|c|c|c|c|c|c|c|c|}
\hline Code & Species & Descriptor & P1 & $\mathbf{P 2}$ & $\mathbf{P 3}$ & P4 & P5 & Total \\
\hline Czeb & Characidium aff. zebra & (Eigenmann, 1909) & 212 & 408 & 282 & 21 & 10 & 933 \\
\hline Pcau & Phalloceros harpagus & Lucinda, 2008 & 202 & 275 & 99 & 0 & 3 & 579 \\
\hline Astysp1 & Astyanax sp. 1 & & 118 & 104 & 44 & 61 & 46 & 373 \\
\hline Hstri & Hypostomus strigaticeps & (Regan, 1908) & 9 & 36 & 181 & 19 & 115 & 360 \\
\hline Trichsp1 & Trichomycterus sp. 1 & & 199 & 93 & 51 & 0 & 0 & 343 \\
\hline Bstr & Bryconamericus stramineus & Eigenmann, 1908 & 4 & 129 & 44 & 90 & 1 & 268 \\
\hline Omic & Odontostilbe aff. microcephala & Eigenmann, 1907 & 1 & 2 & 58 & 82 & 105 & 248 \\
\hline Imir & Imparfinis mirini & Hasemann, 1911 & 110 & 69 & 47 & 1 & 4 & 231 \\
\hline Btur & Bryconamericus turiuba & $\begin{array}{l}\text { Langeani, de Lucena, Pedrini } \\
\text { \& Tarelho-Pereira, } 2005\end{array}$ & 5 & 119 & 67 & 0 & 0 & 191 \\
\hline Apar & Astyanax scabripinnis paranae & Eigenmann, 1914 & 83 & 97 & 6 & 0 & 0 & 186 \\
\hline Cihe & Cetopsorhamdia iheringi & Schubart \& Gomes, 1959 & 57 & 41 & 70 & 6 & 0 & 174 \\
\hline Ccue & Corumbataia cuestae & Britski, 1997 & 2 & 112 & 39 & 5 & 0 & 158 \\
\hline Aalt & Astyanax altiparanae & Garutti \& Britskii, 2000 & 7 & 13 & 42 & 25 & 71 & 158 \\
\hline Aibi & Apareiodon ibitiensis & Amaral Campos, 1944 & 1 & 38 & 71 & 0 & 0 & 110 \\
\hline Pnas & Parodon nasus & Kner, 1859 & 0 & 9 & 86 & 1 & 2 & 98 \\
\hline Aboc & Astyanax bockmanni & Vari \& Castro, 2007 & 3 & 26 & 46 & 8 & 2 & 85 \\
\hline Cfla & Corydoras flaveolus & Ihering, 1911 & 0 & 24 & 32 & 5 & 12 & 73 \\
\hline Imbor & Imparfinis borodini & Mees \& Cala, 1989 & 14 & 25 & 30 & 0 & 0 & 69 \\
\hline Parg & Piabina argentea & Reinhardt, 1867 & 0 & 31 & 25 & 0 & 0 & 56 \\
\hline Rque & Rhamdia quelen & (Quoy \& Gaimard, 1824) & 15 & 15 & 15 & 3 & 6 & 54 \\
\hline Hanc & Hypostomus ancistroides & (Ihering, 1911) & 6 & 4 & 12 & 7 & 20 & 49 \\
\hline Hypsp1 & Hypostomus sp.1 & & 4 & 1 & 25 & 5 & 12 & 47 \\
\hline Gbra & Geophagus brasiliensis & Kner, 1865 & 0 & 3 & 21 & 6 & 2 & 32 \\
\hline Afas & Astyanax fasciatus & (Cuvier, 1819) & 0 & 0 & 11 & 0 & 13 & 24 \\
\hline Aaff & Apareiodon affinis & (Steindachner, 1879) & 0 & 0 & 10 & 1 & 9 & 20 \\
\hline Rlat & Rineloricaria latirostis & (Boulenger, 1900) & 1 & 3 & 7 & 2 & 5 & 18 \\
\hline Hison & Hisonotus sp. & & 0 & 0 & 14 & 3 & 0 & 17 \\
\hline Pimesp1 & Pimelodella sp.1 & & 0 & 0 & 1 & 0 & 12 & 13 \\
\hline Ains & Steidachnerina insculpita & (Fernández-Yépez, 1948) & 0 & 0 & 1 & 1 & 10 & 12 \\
\hline Hher & Hypostomus cf. hermanni & (Ihering, 1905) & 0 & 0 & 10 & 0 & 0 & 10 \\
\hline Neop & Neoplecostomus sp. & & 7 & 0 & 3 & 0 & 0 & 10 \\
\hline Microg & Microglanis cf. garavelloi & & 0 & 0 & 7 & 0 & 0 & 7 \\
\hline Lfri & Leporinus friderici & (Bloch, 1794) & 0 & 0 & 1 & 0 & 5 & 6 \\
\hline Gcar & Gymnotus cf. carapo & Linnaeus, 1758 & 0 & 0 & 6 & 0 & 0 & 6 \\
\hline Hins & Hisonotus insperatus & Britski \& Garavello, 2003 & 0 & 0 & 0 & 5 & 0 & 5 \\
\hline Pret & Poecilia reticulata & Peters, 1859 & 0 & 0 & 2 & 3 & 0 & 5 \\
\hline Evir & Eigenmannia virescens & (Valenciennes, 1836) & 0 & 2 & 0 & 3 & 0 & 5 \\
\hline Isch & Imparfinis schubarti & (Gomes, 1956) & 0 & 0 & 3 & 1 & 0 & 4 \\
\hline Lstr & Leporinus striatus & Kner, 1858 & 0 & 0 & 0 & 0 & 4 & 4 \\
\hline Cgom & Characidium gomesi & Travassos, 1956 & 0 & 0 & 4 & 0 & 0 & 4 \\
\hline Cmod & Cyphocharax modestus & (Fernández-Yépez, 1948) & 0 & 0 & 0 & 0 & 3 & 3 \\
\hline Plin & Prochilodus lineatus & (Valenciennes, 1836) & 0 & 0 & 3 & 0 & 0 & 3 \\
\hline Hequ & Hyphessobrycon eques & (Steindachner, 1882) & 0 & 0 & 3 & 0 & 0 & 3 \\
\hline Hypsp2 & Hypostomus sp.2 & & 0 & 0 & 0 & 1 & 2 & 3 \\
\hline Bryc & Bryconamericus sp. & & 0 & 0 & 1 & 1 & 0 & 2 \\
\hline
\end{tabular}


Table 2. Continued...

\begin{tabular}{cllcccccc}
\hline Code & \multicolumn{1}{c}{ Species } & \multicolumn{1}{c}{ Descriptor } & P1 & P2 & P3 & P4 & P5 & Total \\
\hline Hmal & Hoplias cf. malabaricus & (Bloch, 1794) & 0 & 0 & 0 & 1 & 1 & 2 \\
Cgob & Cetopsis gobioides & Kner, 1858 & 0 & 1 & 1 & 0 & 0 & 2 \\
Hypsp3 & Hypostomus sp.3 & (Gill, 1858) & 0 & 0 & 2 & 0 & 0 & 2 \\
Caen & Corydoras aeneus & 0 & 0 & 1 & 0 & 1 & 2 \\
Sspi & Serrasalmus maculatus & Kner, 1858 & 0 & 0 & 0 & 0 & 2 & 2 \\
Pbri & Planaltina britski & Menezes, Weitzman \& Burns, & 0 & 0 & 0 & 0 & 2 & 2 \\
& & 2003 & & & & & & \\
Loct & Leporinus octofasciatus & Steindachner, 1915 & 0 & 0 & 0 & 0 & 2 & 2 \\
Lpir & Loricaria cf. piracicabae & Ihering, 1907 & 0 & 0 & 0 & 0 & 1 & 1 \\
Cvan & Cyphocharax vanderi & (Britski, 1980) & 1 & 0 & 0 & 0 & 0 & 1 \\
Lvit & Leporellus vittatus & (Valenciennes, 1850) & 0 & 0 & 1 & 0 & 0 & 1 \\
Trichsp2 & Trichomycterus sp.2 & & 0 & 0 & 0 & 0 & 1 & 1 \\
Cjag & Crenicichla jaguarensis & Haseman, 1911 & 0 & 0 & 0 & 0 & 1 & 1 \\
Hyph & Hyphessobrycon sp. & & 0 & 0 & 0 & 0 & 1 & 1 \\
Smar & Synbranchus marmoratus & Haseman, 1911 & 0 & 0 & 0 & 0 & 1 & 1 \\
Hlit & Hoplosternum littorale & (Hancock, 1828) & 0 & 0 & 0 & 0 & 1 & 1 \\
Aden & Aphyocharax dentatus & Eigennmann \& Kennedy, 1903 & 0 & 0 & 0 & 1 & 0 & 1 \\
& & Total & 1061 & 1680 & 1485 & 368 & 488 & 5082 \\
\hline
\end{tabular}
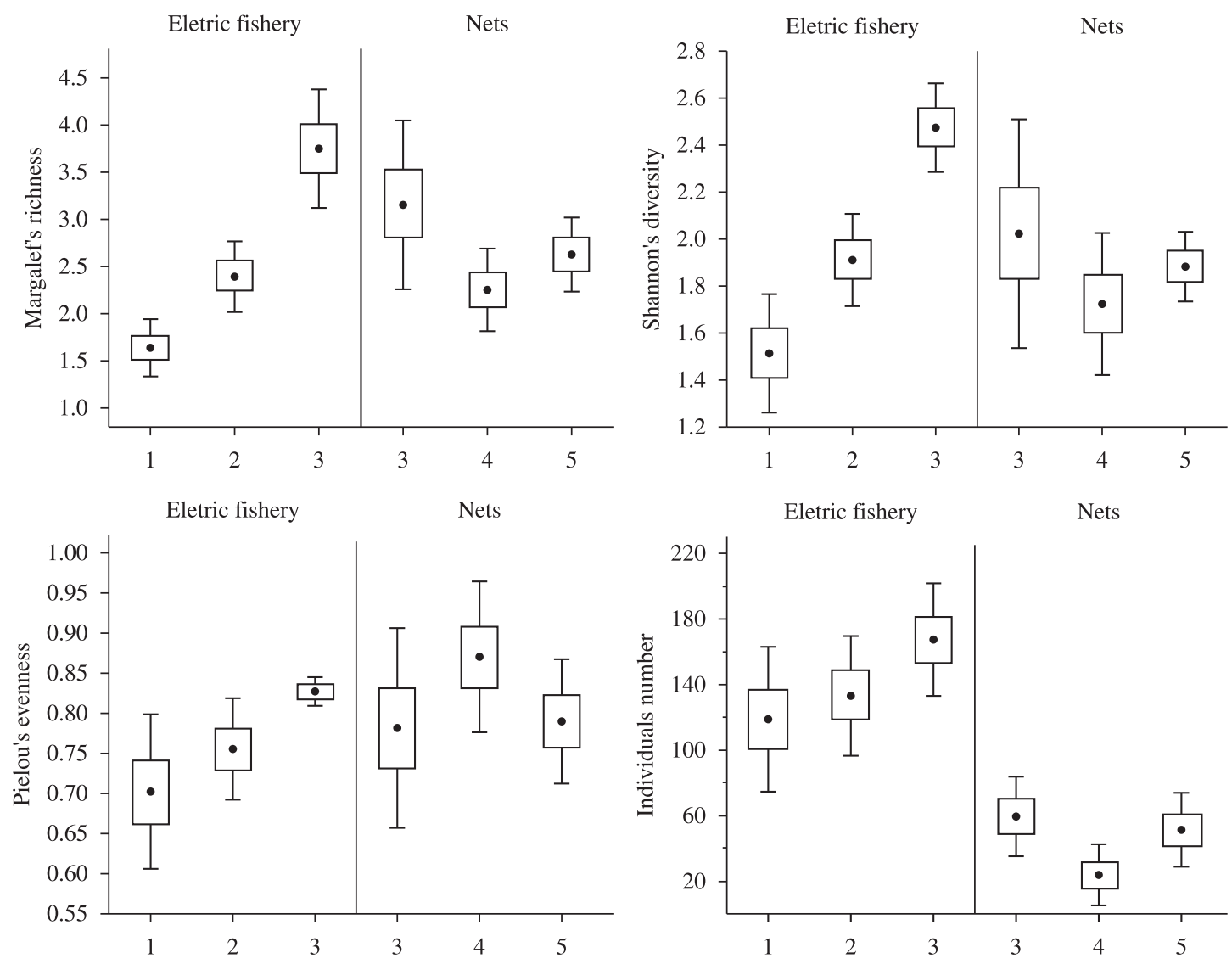

Figure 4. Mean values (•), standard error $(\square)$ and confidence interval 95\% (bars) for the Shannon diversity index, Margalef's richness and Pielou's evenness and number of individuals, considering separately samples from electrofishing and nets. 
Table 3. Number of individuals $(N)$, richness $(S)$ and indices of Shannon's diversity $(H)$, Margalef's richness (MG) and Pielou's evenness $(\mathrm{J})$ for each sample site, considering the different fishery equipment used electric fishery equipment (P1, $\mathrm{P} 2$ and P3) and nets (P3, P4 and P5).

\begin{tabular}{lcccccc}
\hline \multirow{2}{*}{ Eletric fishery } & & $\mathbf{N}$ & $\mathbf{S}$ & $\mathbf{H}$ & MG & J \\
& P1 & 119.0 & 8.7 & 1.5 & 1.6 & 0.7 \\
\multirow{6}{*}{ Gill nets } & P2 & 133.3 & 12.7 & 1.9 & 2.4 & 0.8 \\
& P3 & 167.7 & 20.2 & 2.5 & 3.7 & 0.8 \\
& P3 & 59.5 & 13.7 & 2.0 & 3.2 & 0.8 \\
& P4 & 24.0 & 7.7 & 1.7 & 2.2 & 0.9 \\
\hline
\end{tabular}

Table 4. Table ANOVA for indices of Margalef's richness, Shannon's diversity and Pielou's evenness separately considering the catch with electric fishery (1,2 and 3$)$ and nets $(3,4$ and 5).

\begin{tabular}{|c|c|c|c|c|c|c|c|c|c|c|c|}
\hline & \multicolumn{6}{|c|}{ Eletric fishery (sites 1, 2 and 3) } & \multicolumn{5}{|c|}{ Gill nets (sites 3, 4 and 5) } \\
\hline & FV & df & SQ & QM & $\mathbf{F}$ & $\mathbf{p}$ & df & SQ & $\mathbf{Q M}$ & $\mathbf{F}$ & p \\
\hline \multirow{2}{*}{$\begin{array}{l}\text { Margalef's } \\
\text { richness index }\end{array}$} & Local & 2 & 12.58 & 6.29 & 23.49 & $<0.001$ & 2 & 35.17 & 17.58 & 3.78 & 0.047 \\
\hline & Error & 15 & 40.169 & 2.68 & & & 15 & 69.66 & 4.64 & & \\
\hline \multirow{2}{*}{$\begin{array}{l}\text { Shannon's } \\
\text { diversity index }\end{array}$} & Local & 2 & 2.12 & 1.06 & 35.04 & $<0.001$ & 2 & 0.76 & 0.38 & 3.12 & 0.073 \\
\hline & Error & 15 & 0.45 & 0.03 & & & 15 & 1.83 & 0.12 & & \\
\hline \multirow{2}{*}{$\begin{array}{l}\text { Pielou's } \\
\text { evenness index }\end{array}$} & Local & 2 & 0.030 & 0.015 & 10.01 & 0.001 & 2 & 0.010 & 0.005 & 0.51 & 0.612 \\
\hline & Error & 15 & 0.022 & 0.001 & & & 15 & 0.151 & 0.010 & & \\
\hline
\end{tabular}

FV) Sorce of variation; df) Degrees of freedom; SQ) Sum of squares; QM) Mean square, F) F statistic, p) Probability value.

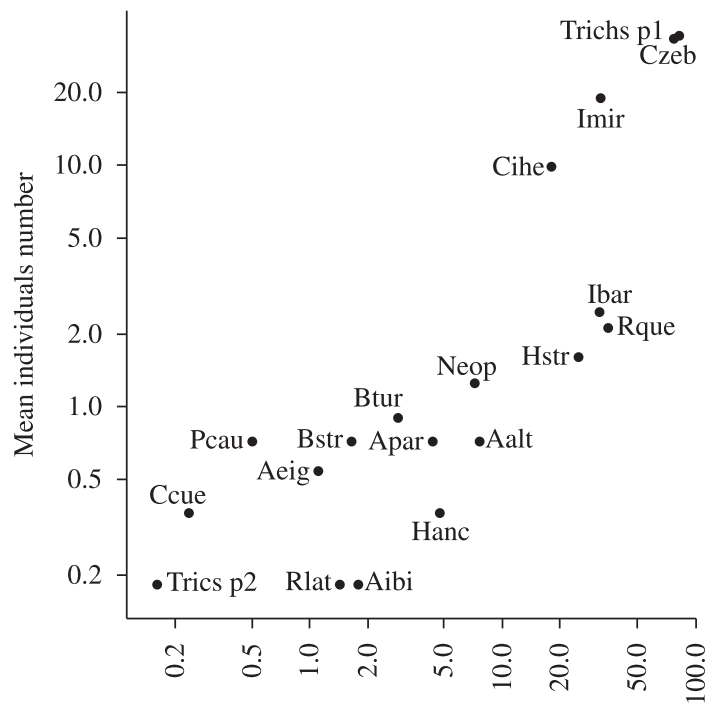

Mean weight (g)

Figure 5. Relationship between weight and number of individuals caught in site 1 , considering the individuals caught using electric fishing (for codes see Table 2).

\section{Discussion}

The Passa Cinco stream has a steep gradient, given its location in the cuestas of São Pedro and Analândia. In the headwaters, the water flow is faster, and the stream is more shallow and narrow. These characteristics directly influence the substrate composition. In such places, the

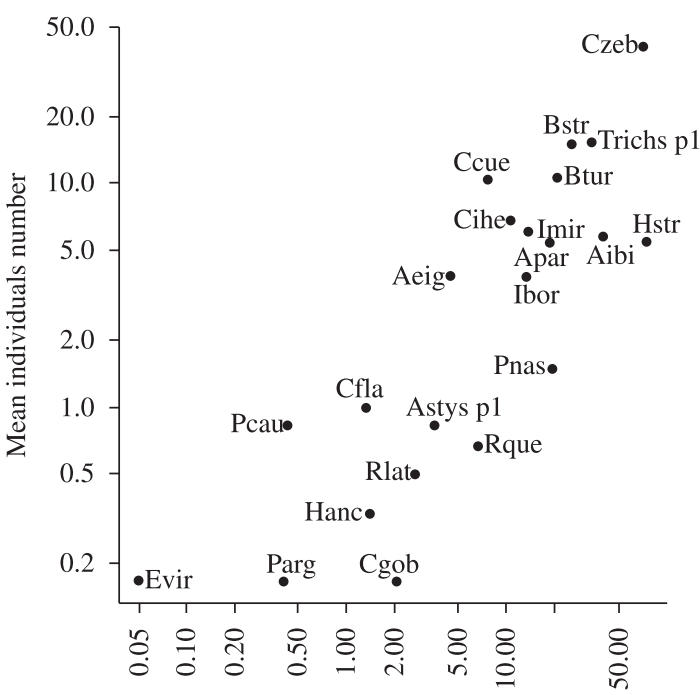

Mean weight (g)

Figure 6. Relationship between weight and number of individuals caught in site 2 , considering the individuals caught using electric fishing (for codes see Table 2).

rocks are slightly larger and little suspended matter or background particulates are verified. All these features will be inverted along the channel. The large amount of water received in a short time, resulting from heavy rains in summer, makes the environment very susceptible to runoff, that quickly raises the water level. The substrate, depth and current are some of the most important physical 


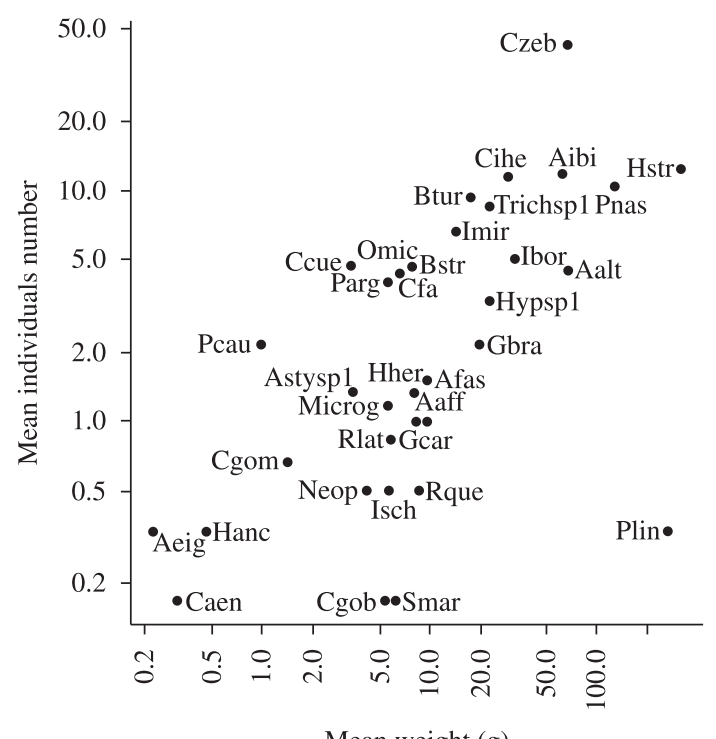

Figure 7. Relationship between weight and number of individuals caught in site 3 , considering the individuals caught using electric fishing (for codes see Table 2).

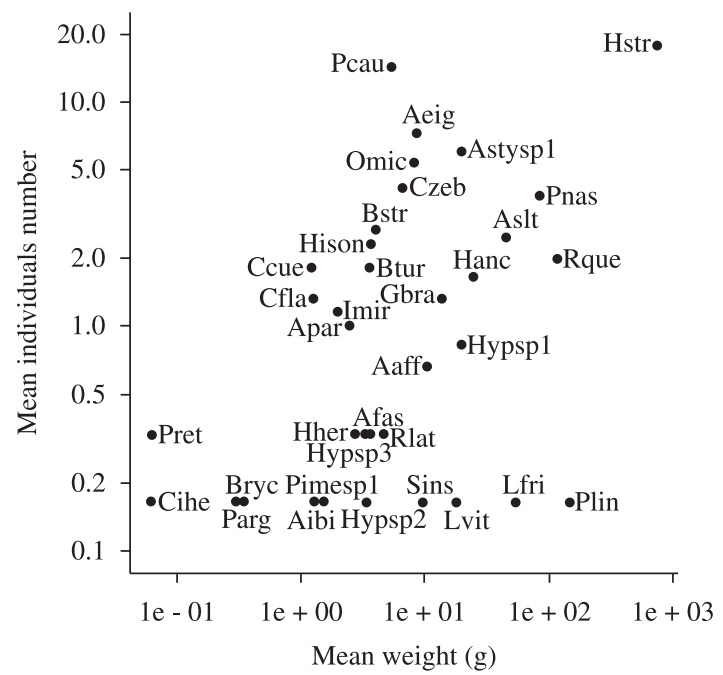

Figure 8. Relationship between weight and number of individuals caught in site 3 , considering the individuals caught using nets (for codes see Table 2).

aspects in determining the distribution of stream fishes (Gorman and Karr, 1978; Argermeier and Karr, 1983). The combination of each aspects of these environmental characteristics produces a mosaic of microhabitats that changes along the gradient according to the physical conditions, which requires adjustments in the biological communities living there (Vannote et al., 1980).

In São Paulo state, the Alto Paraná system includes the major rivers and contains 38 families and 310 species of fish described (Langeani et al., 2007). In association with these major rivers, there is a large number of headwater streams inhabited mainly by species of small fishes with restricted

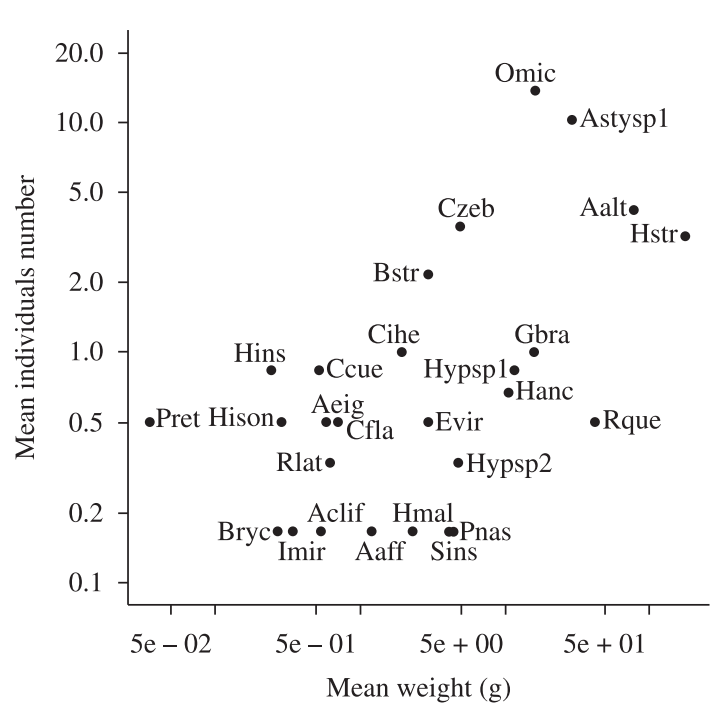

Figure 9. Relationship between weight and number of individuals caught in site 4 , considering the individuals caught using nets (for codes see Table 2).

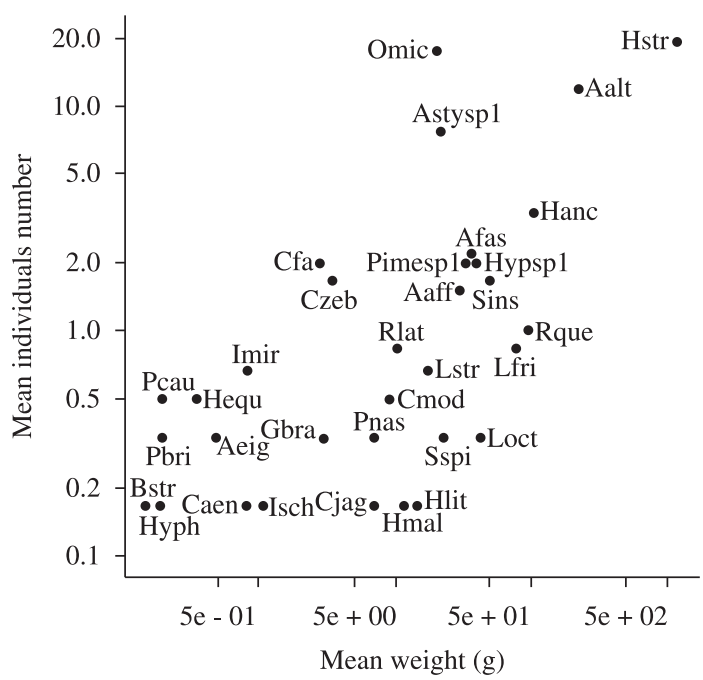

Figure 10. Relationship between weight and number of individuals caught in site 5, considering the individuals caught using nets (for codes see Table 2).

geographic distributions, such as Bryconamericus turiuba, Astyanax bockmanni and Corumbataia cuestae. The Passa Cinco stream is one of these streams with large numbers of small-sized species, some with restricted distributions.

Considering species diversity, richness and evenness, there was an increase from site 1 to 3 , with further decrease in sites 4 and 5, agreeing with the values of the habitat's diversity. These patterns are not due exclusively to the fishery equipment employed, since site 3 was sampled with different equipments. In this site, all values had comparable magnitudes except number of individuals, which was remarkably higher in the electric fishery sites. 
The ANOVA confirmed the increasing pattern of diversity, evenness and richness from site 1 to 3 .

For individuals caught with nets, significant differences were observed only for the richness index. This was because sites 4 and 5 had the lowest number of species. The upstream reaches had lower habitat diversity than the downstream ones (Uieda and Barreto, 1999), which may explain the common pattern of higher species richness at lower portions (Gorman and Karr, 1978). Harrel et al. (1967) apud Peres-Neto (1995) suggest that an increase in species diversity along the river course can occur not only due to an increase in suitable habitats, but also a decrease in environmental fluctuations. The more severe and variable conditions in the headwaters requires from the organisms specific adaptations and higher energy to move against the current and to lessen the likelihood of being swept downstream (Allan, 1997). In more stable sites downstream, where the current is slower or even at a standstill, less energy expenditure is necessary from the individuals to stay in their positions (Allan, 1997).

Although there are fewer species in headwaters sites, there are larger populations, whereas in the downstream sections, the number of species increases and their population densities decrease. The species abundance distribution becomes more homogeneous leading to a higher evenness. This pattern can be seen for sites 1 to 3 (electric fishery) and sites 3 to 4 (gillnets). The same patterns would be expected following the increase in water volume (Garutti, 1988), but in this case, it would be necessary that the environment had a variety of physical structures to provide suitable habitats (Gorman and Karr, 1978; Argermeier and Karr, 1983). On the other hand, when the physical structures inside the stream channel are simplified, the increase in water volume can lead to an environmental homogenisation, as was observed for sites 4 to 5 in the Passa Cinco Stream.

Besides the occurrence and number of individuals, the species importance can also be defined by weight. These three additional measures provide different information about the fish assemblage (Ferreira, 2007). When considering only the species captured with electric fishery, Characidium aff. zebra was the most important species in the first three sample sites, occurring in large numbers and high weight. In addition to $C$. aff. zebra, other species were important for these sites (Trichomycterus sp.1, Imparfinis mirini, Cetopsorhamdia iheringi, Bryconamericus stramineus, B. turiuba, Apereiodon ibitiensis, Parodon nasus e Hypostomus strigaticeps). Headwater stream fishes from different families have morphological traits that allow them to better explore these environments (Braga, 2004). When considering individuals caught with nets (middlelower portions), $H$. strigaticeps was the most important species in site 3, and remained important downstream, joining Odontostilbe aff. microcephala, Astyanax sp.1 and A. altiparanae. We suggest that the species mean abundance and weight are more or less related to population densities at each site. If so, we agree with Mazzoni (1998) that the structural components of the stream channel promote differential resource availability along the longitudinal gradient that, in turn, are correlated to these densities.

\section{Conclusions}

Considering the number of individuals and biomass, as well the changes in diversity, evenness and richness, it was found that, despite the short size of the Passa Cinco stream, the environments are well defined, and structured in headwater, transition (medium-low) and mouth portions. This was evidenced by the species distribution and assemblage composition along the gradient.

Acknowledgements - The authors would like to thank FAPESP (proc. $\mathrm{n}^{\circ}$ 04/12669-3) and CNPq for financial support, IBAMA (proc. $\mathrm{n}^{\circ}$ 02027.000234/2005-05) for authorising the license for the execution of fieldwork, professors Julio C. Garavello, Francisco Langeani and Heraldo A. Britski for fish identification, the designer Jaime R. Somera for map confection, and the two anonymous reviewers for suggestions proposed.

\section{References}

ALLAN, JD., 1997. Stream Ecology: structure and function of running water. New York: Chapman and Hall. 338 p.

ARGERMEIER, PL. and KARR, JR., 1983. Fish communities along environmental gradients in a system of tropical streams. Environmental Biology of Fishes, vol. 9, no. 2, p. 117-135. http:// dx.doi.org/10.1007/BF00690857

BALON, EK. and STEWART, DJ., 1983. Fish assemblage in a river with unusual gradient (Luongo, Africa-Zire system), reflections on river zonation, and description of another new species. Environmental Biology of Fishes, vol. 9, p. 225-252. http://dx.doi.org/10.1007/BF00692373

BENEDITO-CECILIO, E., MINTE-VERA, CV., ZAWADZKI, CH., PAVANELLI, CS., RODRIGUES, FHG. and GIMENES, MF., 2004. Ichthyofauna from the emas national park Region: composition and structure. Brazilian Journal of Biology, vol. 64, no. 3A, p. 371-382. http://dx.doi.org/10.1590/S1519-69842004000300002

BRAGA, FMS., 2004. Hábitat, distribuição e aspectos adaptativos de peixes da microbacia do Ribeirão Grande, Estado de São Paulo, Brasil. Acta Scientiarum, vol. 26, no. 1, p. 31-36.

BRAGA, FMS. and ANDRADE, PM., 2005. Distribuição de peixes na microbacia do Ribeirão Grande, Serra da Mantiqueira Oriental, São Paulo, Brasil. Iheringia Série Zoologia, vol. 95, no. 2, p. 121-126.

CASATTI, L., 2005. Fish assemblage structure in a first order stream, southeastern Brazil: longitudinal distribution, seasonality, and microhabitat diversity. Biota Neotropica, vol. 5, no. 1, p. 1-9. http://dx.doi.org/10.1590/S1676-06032005000100009

CASTRO, RMC., CASATTI, L., SANTOS, HF., FERREIRA, KM., RIBEIRO, AC., BENINE, RC., DARDIS, GZP., MELO, ALA., STOPIGLIA, R., ABREU, RX., BOCKMANN, FA., CARVALHO, M., GIBRAN, FZ. and LIMA, FCT., 2003. Estrutura e composição da ictiofauna de riachos do rio Paranapanema, sudeste do Brasil. Biota Neotropica, vol. 3, no. 1, p. 1-31.

CASTRO, R MC., CASATTI, L., SANTOS, HF., MELO, ALA., MARTINS, LSF., FERREIRA, KM., GIBRAN, FZ., BENINE, RC., CARVALHO, M., RIBEIRO, AC., ABREU, TX., BOCKMANN, FA., PELIÇÃO, GZ., STOPLIGIA, R. and LANGEANI, F., 2004. Estrutura e composição da ictiofauna de riachos da bacia do Rio Grande no estado de São Paulo, sudeste do Brasil. Biota Neotropica, vol. 4, no. 1, p. 1-39. 
CETRA, M. and PETRERE, M., 2006. Fish assemblage structure of the Corumbataí River Basin, São Paulo State, Brazil: characterization and anthropogenic disturbances. Brazilian Journal of Biology = Revista Brasileira de Biologia, vol. 66, no. 2A, p. 431-439.

EDDS, DR., 1993. Fish assemblage structure and environmental correlates in Nepal's Gandaki river. Copeia, no. 1, p. 48-60.

FERREIRA, FC., 2007. Ictiofauna de riachos na planície costeira da bacia do rio Itanhaém, litoral sul de São Paulo. Rio Claro: Universidade Estadual Paulista. Dissertação de Mestrado em Zoologia.

FERREIRA, FC. and PETRERE, M., 2009 The fish zonation of the Itanhae'm river basin in the Atlantic Forest of southeast Brazil. Hydrobiologia, vol. 636, p.11-34. http://dx.doi.org/10.1007/ s10750-009-9932-4

GARCIA, GJ., HEBERT, HD., PERINOTTO, JAJ. and CASTRO, JFM., 2004. Atlas ambiental da bacia do rio Corumbataí. Avaliable from: <http://ceapla.rc.unesp.br/atlas/>. Acess in: 13 mar. 2004.

GARUTTI, V., 1988. Distribuição longitudinal da ictiofauna em um córrego da região noroeste do Estado de São Paulo, bacia do rio Paraná. Revista Brasileira de Biologia = Brazilian Journal of Biology, vol. 48, no. 4, p. 747-759.

GILLIAM, JF., FRASER, DF. and ALKINS-KOO, M., 1993. Structure of a tropical stream fish community: a role for biotic interactions. Ecology, vol. 74, p. 1856-1870. http://dx.doi. org/10.2307/1939943

GOMIERO, LM. and BRAGA, FMS., 2006. Diversityf of the ichthyofauna in the Serra do Mar State Park - Núcleo Santa Virgínia, São Paulo state, Brazi. Acta Sientiarium, vol. 28, no. 3, p. 213-218.

GORMAN, OT. and KARR, JR., 1978. Habitat structure and stream fish communities. Ecology, vol. 59, no. 3, p. 507-515. http://dx.doi.org/10.2307/1936581

JACKSON, DA., PERES-NETO, PR. and OLDEN, JD., 2001. What controls who is where in freshwater fish communities - the rules of biotic, abiotic, and spatial factors. Canadian Journal Fish Aquatic Science, vol. 58, p. 157-170.

LANGEANI, F., CASTRO, RMC., OYAKAWA, OT., SHIBATTA, OA., PAVANELLI, CS. and CASATTI, L., 2007. Diversidade da ictiofauna do Alto Rio Paraná: composição atual e perspectivas futuras. Biota Neotropica, vol. 7, no. 3, p. 181-197. http://dx.doi. org/10.1590/S1676-06032007000300020

MATTHEWS, WJ., 1998. Patterns in freshwater fish ecology. New York: Chapman and Hall.

MATTHEWS, WJ. and STYRON, J T., 1981. Tolerance of headwater vs. mainstream fishes for abrupt physicochemical changes. American Midland Naturalist, vol. 105, p. 149-158. http://dx.doi.org/10.2307/2425020

MAZZONI, R., 1998. Estrutura das Comunidades e Produção de Peixes de um Sistema Fluvial Costeiro de Mata Atlântica, Rio de Janeiro. São Carlos: Universidade Federal de São Carlos. Tese de Doutorado em Ecologia e Recursos Naturais.

MAZZONI, R. and LOBÓN-CERVIÁ, J., 2000. Longitudinal structure, density and production rates of a neotropical stream fish assemblage: the river Ubatiba in the Serra do Mar, southeast Brazil. Ecography, vol. 23, p. 588-602. http://dx.doi.org/10.1034/j.16000587.2000.230510.x

MONTAG, LFA., SMITH, WS., BARRELLA, W. and PETRERE, M., 1997. As influências e as relações das matas ciliares nas comunidades de peixes do estado de São Paulo. Revista Brasileira de Ecologia, vol. 1, p. 76-80.

PAVANELLI, CS. and CARAMASCHI, EP., 2003. Temporal and spatial distribution of the ichthyofauna in two streams of upper rio Paraná basin. Brazilian Archives Biology and Technology, vol. 46 , no. 2, p. 271-280.

PERES-NETO, PR., 1995. Estrutura de comunidades de peixes ao longo de um gradiente lótico de um rio costeiro do leste brasileiro (rio Macacu, RJ). Rio de Janeiro: Universidade Federal do Rio de Janeiro. Dissertação de Mestrado em Ecologia.

PETRY, AC. and SCHULTZ, U H., 2006. Longitudinal changes and indicator species of the fish fauna in the subtropical Sinos River, Brazil. Journal of Fish Biology, vol. 69, p. 272-290. http:// dx.doi.org/10.1111/j.1095-8649.2006.01110.x

RONDINELI, GR. and BRAGA, FMS., 2009. Biologia populacional de Corydoras flaveolus no rio Passa Cinco, sub-bacia do rio Corumbataí, São Paulo, Brasil. Biota Neotropica, vol. 9, no. 4. Avaliable from: <http://www.biotaneotropica.org.br/v9n4/pt/abs tract?article+bn00809042009>. Acess in: 10 jan. 2010

SILVANO, RAM., AMARAL, BD. and OYAKAWA, OT., 2000. Spatial and temporal patterns of diversity and distribution of the Upper Juruá River fish community (Brazilian Amazon). Environmental Biology of Fishes, vol. 57, p. 25-35. http://dx.doi. org/10.1023/A:1007594510110

STRAHLER, AL., 1952. Dynamics basis of geomorphology. Geological Society of America, vol. 63, p. 923-938.

SÚAREZ, YR. and PETRERE, M., 2003. Associação de espécies de peixes em ambientes lóticos da bacia do rio Iguatemi, Estado de Mato Grosso do Sul. Acta Scientiarium, vol. 25, no. 2, p. 361-367.

SÚAREZ, YR. and PETRERE, M., 2005 Organização das assembléias de peixes de riachos da bacia do rio Iguatemi, Mato Grosso do Sul. Acta Scientiarum, vol. 27, no. 2, p. 161-167.

UIEDA, V S., 1984. Ocorrência e distribuição dos peixes em um riacho de água doce. Revista Brasileira de Biologia $=$ Brazilian Journal of Biology, vol. 44, no. 2, p. 203-213.

UIEDA, VS. and BARRETO, MG., 1999. Composição da ictiofauna de quatro trechos de diferentes ordens do rio capivara, Bacia do Tietê, Botucatu, São Paulo. Revista Brasileira de Zoociências, vol. 1 , no. 1 , p. 55-67.

UIEDA, VS. and UIEDA, W., 2001. Species composition and spatial distribution of a stream fish assemblage in the east coast of Brazil: comparasion of two field study methodologies. Brazilian Journal of Biology, vol. 1, no, 3, p. 377-388.

VALENTE, ROA. and VETTORAZZI, CA., 2002. Análise da estrutura da paisagem na bacia do rio Corumbataí, SP. Scientia Florestalis, vol. 62, p. 114-129.

VANNOTE, RL., MINSHALL, GW., CUMMINS, KW., SEDELL, JR. and CUSHING, CE., 1980. The river continuum concept. Canadian Journal Fish Aquatic Science, vol. 37, p. 130-137. http://dx.doi.org/10.1139/f80-017

WILKISON, CD. and EDDS, DR., 2001. Spatial pattern and environmental correlates of a midwestern stream fish community: including spatial autocorrelation as a factor in community analyses. American Midland Naturalist, vol. 146, p. 271-289. http://dx.doi. org/10.1674/0003-0031(2001)146[0271:SPAECO]2.0.CO;2

WINEMILLER, KO. and LESLIE, MA., 1992. Fish assemblages across a complex, tropical freshwater/marine ecotone. Environmental Biology of Fishes, vol. 34, p. 29-50. http://dx.doi.org/10.1007/ BF00004783 